\title{
A Natureza Jurídica dos Encargos Emergenciais de Energia Elétrica ("Sequro Apagão")
}

\author{
Luis Antônio Alcoba de Freitas
}

\section{INTRODUÇÃo}

Cabe, inicialmente, declinar a razão da escolha do tema da monografia. Efetivamente as matérias abordadas, relativas ao recolhimento dos encargos tarifários instituídos pela Lei $n^{\circ} 10.438 / 02$, popularmente chamados de "seguro-apagão", destacados do valor da tarifa, portanto visiveis ao olho e ao bolso do usuário, não se afiguram simpáticas ao consumidor do serviço de energia elétrica, ainda mais num país como o nosso, onde a carga tributária alcança níveis insuportáveis, chegando a Quase $40 \%$ do PlB, sem falar nos preços públicos oriundos dos serviços prestados à população.

No ano de 2001, o Brasil enfrentou uma grave crise energética, provocada por contingências climáticas, abalando o Sistema Elétrico Brasileiro, Quase na sua totalidade formado por hidrelétricas. Para evitar o apagão nas cidades a solução encontrada, à época, objetivando superar a crise energética e o colapso do sistema, foi direcionada em duas direçôes, a saber: uma agindo na ponta do consumo, através de medidas restritivas (inclusive criando encargos financeiros para os consumidores que ultrapassassem suas Quotas); e outra, na ponta da geração, buscando seu aumento em curto prazo. Sobre a última é que desenvolveremos a pesquisa, para verificar a natureza jurídica dos encargos emergenciais.

Muitas críticas surgiram sobre as medidas adotadas para contornar os problemas de falta de energia elétrica, decorrentes de circunstâncias climáticas desfavoráveis, Que provocaram um rebaixamento extremo dos reservatórios das usinas hidroelétricas, afetando a produção e, segundo alguns, também da falta de investimentos oportunos. 
A escolha tem um caráter institucional. A Advocacia-Geral da União, como uma instituição de Estado, teve Que exercer a sua atribuição constitucional na defesa da política pública implementada pelo Governo Federal. A matéria foi judicializada, exigindo dos membros da Instituição, especialmente no âmbito do Tribunal Regional da $4^{a}$ Região, onde foi suscitado incidente de inconstitucionalidade', uma atuação intensa para demonstrar a constitucionalidade e a legalidade da criação dos adicionais tarifários.

É de se frisar que não se entra no mérito político da criação dos adicionais tarifários como methor alternativa, ou não, à situação existente à época. Esse julgamento cabe à população, Que sofreu as conseqüências das medidas adotadas. Nem por isso, se deixará de analisar as causas da criação e a forma como foi operacionalizada a decisão política. Como dizia Carlos Maximiniano ${ }^{2}$, para ser hermeneuta completo, é mister entesourar profundo conhecimento de todo o organismo do Direito e cognição sólida não só da história dos institutos, mas também das condições de vida em que as relações se formam. O que se busca no presente trabalho de pesquisa é a interpretação técnica dos encargos criados sob o enfoque do ordenamento jurídico do nosso país

A questão Que se coloca: a contratação de energia emergencial, através de encargos tarifários, destacados do valor da tarifa, por empresa pública, criada especificamente para este fin, Que não é distribuidora direta da energia, na busca de fontes alternativas a água, escassa naquele momento histórico do nosso país, tem caráter tributário ou tarifário?

A doutrina e a jurisprudência têm se dividido sobre a Questão. Existem abalizados posicionamentos para ambos os lados, enQuadrando nas mais variadas categorias de tributo, tais como taxa, contribuição social geral, CIDE, espécie anômala de empréstimo compulsório, imposto inominado e como um adicional tarifário. Os Tribunais Superiores ainda não se manifestaram sobre o mérito da Questão. Existe uma Ação Direta de Inconstitucionalidade Adin no 2693 - ajuizada pela Ordem dos Advogados do Brasil. pendente de julgamento no Supremo Tribunal Federal. O Tribunal Regional Federal da $4^{a}$ Região, único Tribunal Regional Federal Que enfrentou o mérito da matéria, consolidou posicionamento, anteriormente dividido nos seus órgãos fracionários ( $I^{\mathrm{a}} \mathrm{e} 2^{\mathrm{a}}$ Turma). Recentemente, em face de argüiçẫo de inconstitucionalidade suscitada pela $2^{\mathrm{a}}$ Turma do Tribunal Regional Federal da $4^{\mathrm{a}}$ Região, a Corte Especial daquele Pretório decidiu, por nove votos a seis, Que o encargo emergencial é constitucional e tem natureza tarifária.

' O incidente de argüição de inconstitucionalidade foł suscitado na apelação em Mandado de Segurança no 2002.72.05.002803-3/SC e Julgado pela Corte Especial do Tribunal Regional Federal da 4a Regiăo, em 26.08.2004

2 MAXIMIliano, Carlos. Hermenêutica e aplicaçăo do direito. Rio de Janeiro: Fotense, 1984, p. 100. 
Verifica-se, portanto, Que a matéria é extremamente polêmica, comportando interpretações diversas. De outra parte, existe pouca coisa escrita, sendo produtivo discorrer sobre o tema, abordando os vários aspectos Que o cercam, a partir da experiência vivida entre os operadores do direito. Neste particular, importante a contribuição colhida das manifestações produzidas pelos Magistrados, Advogados privados, Membros do Ministério Público e da Advocacia Pública ${ }^{3}$.

A partir da definição da natureza jurídica dos referidos encargos, é que poderemos verificar a sua constitucionalidade. Para esta compreensão faz-se necessário trazer à consideração alguns conceitos envolvendo a definição de tributo e de tarifa, Que, necessariamente, deverão ser cotejados conjuntamente com a realidade do funcionamento do Setor Elétrico Brasileiro, Que possui peculiaridades próprias, especialmente após a desestatização do setor.

Na hipótese de ser enQuadrada como de natureza tributária teria que se sujeitar aos princípios contidos no artigo 150 da Constituição Federal de 1988, como o da legalidade e o da anterioridade, com destaque para fixação da exação, Que deveria ser fixada por lei, segundo os Que defendem esta tese.

Outros aspectos necessariamente devem ser dissecados, como o caráter da prestação do serviço de energia elétrica (compulsoriedade e essencialidade), fundamentais na conceituação tributária. Por outro lado, tratando-se de adicional tarifário destacam-se Questões como a relação dos usuários do serviço e a efetiva contraprestação do serviço. O fato de o valor arrecadado ser repassado a Comercializadora Brasileira de Energia Elétrica é outro ponto a ser abordado, tendo em vista ser um dos argumentos para desnaturar a condição de tarifa. Cabe destacar que, em sendo considerada de natureza tributária, a conseqüência é o da inconstitucionalidade do encargo emergencial, o Que obrigaria a devolução dos valores cobrados no período de sua existência, estimado pela Companhia Brasileira de Energia Emergencial em nove bilhões de reais.

\section{O SISTEMA ELÉTRICO BRASILEIRO E OS ENCARGOS EMERGENCIAIS DA LEI N' 10.438/02}

\subsection{NOVA MODELAGEM DO SISTEMA ELÉTRICO BRASILEIRO}

Para Que possamos compreender a natureza jurídica dos encargos emergenciais é imprescindivel conhecermos um pouco da estrutura e do funcionamento do Sistema Elétrico Brasileiro.

3 Especialmente o trabalho denominado "Açöes envolvendo a $\mathrm{MP} / 4$ " elaborado pela CONSULTORIAGERAL. DA UNIÃO. Coordenäacão-Gerał de Grupos Especiais. Fonte: www.agu.gov.br. 
A Constituição Federal outorga competência à União para explorar os serviços de energia elétrica ${ }^{4}$. É o ente federal, assim, Que pode prestar diretamente ou através de concessão, na Qualidade de poder concedente,

Historicamente, antes da edição da Constituição de 1988 , incentivados pelas políticas públicas nacionais para o setor, os Estados Federados, criaram empresas Que obtiveram a concessão dos serviços de geração, transmissão e distribuição de energia elétrica, como é o caso da Companhia Estadual de Energia Elétrica no Estado do Rio Grande do Sul.

Praticamente todo o setor elétrico estava nas mãos do Estado (União e Estados Federados). A partir da Lei no $8.031 / 90$ e da Lei n ${ }^{\circ} 9.491 / 97$, estabeleceram-se às bases legais para a implementação do Programa Nacional de Desestatização (PND), sendo incluídas as empresas do setor elétrico através do Decreto ${ }^{\circ} 1.503 / 95$.

A justificativa estava calcada no fato de Que o setor público estava exaurido, não tendo mais condições de investir numa área estratégica para o desenvolvimento do país. Esta realidade é bem retratada na Obra " O Novo Modelo do Setor Elétrico Brasileiro e as Cooperativas de Eletrificação Rural ${ }^{5}$ :

De um contexto estalista, em Que o serviço era prestado principalmente, por empresas vinculadas às Administrações Públicas federal e estadual, com tarifas homogêneas em todo território nacional - estabelecidas pelo sistema da remuneração pelo custo do serviço-estamos passando a um ambiente de prestação de serviço por particulares concessionários em regime de competição - onde tal seja economicamente possível-, com tarifas diferenciadas e transações de compra e venda de energia em regime de mercado, com limites e dúvidas adiante apresentados. Nesse novo modelo, salienta-se o papel regulador do Estado, realizado pelas "Agências", no caso da energia elétrica, pela Agência Nacional de Energia Elétrica- ANEEL, um autarquia com regime especial, instituída pela Lei $n^{\circ} 9.427$, de 26 de dezembro de 1996, e constituída pelo Decreto $\mathrm{n}^{\circ} 2.335$, de 06 de outubro de 1997.

4. Art. 175. Incumbe ao Poder Público, na forma da lei, diretamente ou sob regime de concessão ou permissão, sempre através de licitação, a prestação de serviços púbłicos.

Parágrafo único. A lei disporá sobre:

1- o regime das empresas concessionárias e permissionárias de serviços públicos, o caráter especial de seu contrato e de sua prorrogaçăo, bem como as condiçôes de caducidade fiscalização e rescisão da concessão ou permissão;

[1-os direitos dos usuários;

[I]- política tarifária;

IV- a obrigação de manter serviço adequado.

5 SOUTO, Carlos Fernando E.; LOUREIRO, Gustavo Kaercher. O novo modelo do setor elétrico brasileiro e as Cooperativas de Eletrificação Rural. Porto Alegre: Livraria do Advogado, 1999. 
Não se entra no mérito da discussão, Que exigiria longa discussão sobre privatização versus estatização, em razão de não ser o objetivo do trabalho. Apenas reflete-se a realidade existente, componente importante para respondermos as indagações propostas pelo presente trabalho de pesquisa.

$\mathrm{Na}$ implementação da política de desestatização do Setor Elétrico, um marco importante é a Edição da Lei no $9.074 / 95$, Que desmembrou as atividades de geração, transmissão e distribuição, passando as tarifas a serem calculadas com base na estrutura de custos de cada um desses segmentos, havendo a previsão da existência de consumidores livres e competição na geração e na comercialização.

Esta nova realidade permitiu a existência dos chamados "Produtores Independentes de Energia Elétricá ${ }^{6}$, Que são, por exemplo, empresas que têm alta demanda de energia elétrica e a produzem na alimentação de seu parque industrial, sendo as sobras comercializadas.

Mais recentemente, através da Lei n ${ }^{\circ}$ 10.848/2004, Que estabeleceu nova modelagem do setor elétrico brasileiro, esta realidade não foi alterada. Apenas, a título exemplificativo. menciona-se a alteração trazida pela nova lei, segundo a Qual as concessionárias, as permissionárias e as autorizadas de serviço público de distribuição de energia elétrica Que atuem no sistema interligado nacional não poderão desenvolver atividades de geração de energia elétrica e de transmissão de energia elétrica $\left(\S^{\circ}\right.$ da Lei $n^{\circ} 9.074$, incluído pela Lei $n^{\circ}$ 10.848, de 2004). É a chamada desverticalização do setor elétrico.

lá dá para perceber, no que toca a operação, Que o sistema é composto basicamente de três setores: o da geração de energia, o de sua transmissão e o de sua distribuição (ou comercialização, como muitos chamam). Todos estes serviços são remunerados pela tarifa Que é recebida pela distribuidora, última na ponta da cadeia. Este fator é importante para que possamos analisar, posteriormente, o argumento da destinação ao prestador do serviço, elemento essencial da tarifa.

Alguns dados dão a dimensão atual do setor elétrico7:

Geração: $\quad 85 \%$ setor público

$15 \%$ setor privado

Transmissão: 26 empresas ( 15 privadas)

Distribuição: 64 empresas ( $80 \%$ setor privado)

- O produtor independente de energia elétrica está definido no artigo 1 I da lei no 9074, de 07/07/95, como "a pessoa jurídica ou empresas reunidas em consórcio que recebem concessão ou autorização do poder concedente, para produzir energia elétrica destinada ao comércio de toda ou parte da energia produzida, por sua conta e risco".

7 Fonte: Ministério das Minas e Energia - BEM 2005- uww.rnme.govbr 
De outra parte, Quase a totalıdade de nossa capacidade instalada de produção de energia elétrica, está calcada em Hidrelétricas, em face do grande manancial de água do nosso país. São muito pequenos os percentuais das outras fontes de energia, como o gás natural, nuclear, derivados de petróleo, carvão, eólica e de fontes naturais, como o álcool e o substituto do óleo diesel, o chamado biodiese!.

Outra particularidade do bem energia elétrica é a de Que, ao contrário de outros bens, não pode ser armazenado por motivos de restrições técnicas. Em virtude disso toda energia elétrica tem Que ser utilizada em uma região ou outra.

O Sistema Elétrico Nacional é interligado, ou seja, foi estabelecido por um sistema de vasos comunicantes em que a energia gerada em um ponto do País poderá ser enviada a Qualeuer outro, de forma a compensar os desníveis regionais de produçâo, decorrentes de fatores climáticos.

Esta situação está muita bem retratada por Clever M. Campos ${ }^{8}$ :

O sistema nacional interligado, onde as transações com o bem energia elétrica se efetuam, pode ser entendido, analogicamente, a um sistema de caixa único, onde todos os geradores injetam energia elétrica e todos os consumidores retiram energia elétrica consumida, para depois, com base em dados de mediçôes, realizar-se um balanço,apurando-se quem gerou e Quem consumiu, objetivando um encontro de contras de caráter comercial. No Brasil, a supervisão destas tarefas está a cargo do NOS - Operador Nacional do Sistema e da ASMAE-Administradora de Serviço do Mercado Atacadista de Emergia Elétrica.

No Brasil, após a edição da Lei no 10.848/2004, a supervisão destas Tarefas está a cargo do Operador Nacional do Sistema (ONS), responsável pela operação do Sistema Interligado Nacional, e pela Câmara de Comercialização de Energia Elétrica (CCEE), responsável pelo gerenciamento dos contratos e pela contabilização e liQuidação de curto prazo.

Verifica-se, portanto, Que o denominado Sistema Elétrico Interligado Nacional é composto por agentes atuando em três etapas distintas, todas remuneradas pelo preço pago pelo consumidor final ao distribuidor, Que repassa os valores correspondentes às demais concessionárias ou autorizadas de geraçăo e transmissão.

Neste contexto, o consumidor paga pela energia efetivamente gerada (distribuição), a capacidade de geração (geração) e o transporte (transmissão), não se podendo deixar de calcular os custos de todas estas etapas integrantes do Sistema Interligado, inclusive o Operador Nacional do Sistema, Que é uma pessoa jurídica de direito privado? .

8 CAMPOS, Clever M. Introdução ao direito de energia elétrica. São Paulo: ícone, 2001.

? Lei $n^{\circ} 9.648$, de 27 de máo de 1998 e Resoluçăo da ANEEL. $n^{\circ} 351$, de 11 de novembro de 1998. 
A capacidade de geração (ou demanda de potência), assim, também é remunerada pela tarifa paga pelo consumidor final. Já era assim, desde que foi fixada a estrutura tarifária de energia elétrica no país, através do Decreto $62.724 / 68 .^{10}$ Ou seja, o planejamento do setor prevê, além da energia efetivamente gerada, também as margens de garantia pondo os consumidores a salvo de riscos sempre presentes de interrupção do fornecimento ou racionamento.

A nova modelagem do setor elétrico, prevista na Lei n ${ }^{\circ} 10.848 / 2004$, também previu a capacidade de geração, no seu artigo $3^{\circ}$, estabelecendo que "O Poder Concedente homologará a Quantidade de energia elétrica a ser contratada para o atendimento de todas as necessidades do mercado nacional, bem como a relação dos novos empreendimentos de geração Que interligarão, a título de referência, o processo licitatório de contratação de energia". O $\S 3^{\circ}$ estabelece: "Com vistas em garantir a continuidade de fornecimento de energia elétrica, o Poder Concedente poderá definir reserva de capacidade de geração a ser contratada". A definição veio através da edição do Decreto no 5.163 , de 30 de julho de $2004^{11}$.

\subsection{A CRIAÇÃO DOS ENCARGOS EMERGENCIAIS E DA COMERCIALIZADORA BRASILEIRA DE ENERGIA EMERGENCIAL - CBEE}

Após a implantação do programa de racionamento e do esforço exigido da população em razão da escassez de energia elétrica ocorrida em 2001, o país não poderia manter a vulnerabilidade do Sistema Interligado Nacional - SIN aos cenários hidrológicos. Era fundamental criar condiçôes Que resultassem em um contexto de maior segurança para o Sistema: aumentar a oferta de energia em curtíssimo prazo.

30 Art. 11. As tarifas a serem apłicadas aos consumidores do Grupo A serão estruturadas sob forma binômia, com uma componente de demanda de potência e outra de consumo de energia.

O artigo 14 do mesmo Decreto estipula que "O custo do serviço de fornecimento de energia elétrica deverá ser repartido, entre os componentes de demanda de potência e de consumo de energia de modo que cada grupo ou subgrupo, se houver, de consumidores, responda pela fração Que the couber.

O parágrafo primeiro deste artigo dìz que a componente de demanda de potência será responsável pelo atendimento do custo do serviço, composto pela remuneraçăo legal, Quota de reversão ou de amortização se houver, quota da demanda de potência adquirida e diferenças referidas no art. 166 . parágrafos $3^{\circ}$ e $4^{\circ}$ do Decreto 41.019/57. Do parágrafo segundo do citado artigo consta que a componente de consumo de energia deveráa atender despesas de exploração, inclusive a parcela relativa ao custo de demanda de potência adquirida, atribuída à componente de demanda de potência, além de impostos e taxas.

1: Art. 59 -... As regras e procedimentos de comercialização da CBEE poderão prever o pagamento de um encargo destinado à cobertuła dos custos dos serviços do sistema, incłusive serviços ancilares, prestados aos usuários do SIN, Que compreenderão, dentre outros: custos decorrentes da geração despachada independenteinente da ordem de mérito, por restrições de transmissão dentro de cada submercado; a reserva de potência operativa, em MW, disponibilizada pelos geradores para a regulação da freqüência do sistema e sua capacidade de partida autônona; a reserva de capacidade, em MV Ar, disponibilizada pelos geradores, superior aos valores de referência estabelecidos para cada gerador em Procedimentos de Rede do NOS, necessária para a operaçăo do sistema de transmissão; e a operaçāo dos geradores como compensadores síncronos, a regulação da tensão e os esquemas de corte de geração e alívio de cargas. 
Desta constatação, o Governo por Intermédio da Câmara de Gestão da Crise de Energia, instituída com o objetivo de compatibilizar a demanda e a oferta de energia elétrica e prevenir risco de "apagões", instituiu um conjunto de medidas com o objetivo de promover a superação da crise. Diante da urgência e do volume de energia a ser contratado, fazia-se imprescindivel Que a contratação de energia fosse centralizada em apenas uma entidade, a Qual seria responsável pela assinatura dos contratos de compra de energia elétrica e/ou capacidade de energia com os produtores independentes e pelo repasse ao Sistema Interligado Nacional, composto pelas concessionárias distribuidoras. Delineou-se, então, o programa de energia implementado pela Comercializadora Brasileira de Energia Emergencial - CBEE, criada em 29 de agosto de 200 l (Decreto n 3.900 , de 29 de agosto de 2001, em cumprimento a Lei $n^{\circ} 10.438$, de 26 de abril de 2002) .

A criação da CBEE foi oriunda dos trabalhos desenvolvidos pelo Comitê Técnico de Aumento da Oferta de Energia a Curto Prazo, criado pela Resolução da Câmara de Gestão da Crise de Energia Elétrica de-CGE no 14, de 06 de junho de 2001. Daí se extrai algumas justificativas para criação da empresa pública, Que são relevantes para compreensão da criação da CBEE e dos encargos tarifários. No desenvolvimento dos trabalhos, o Comitê definiu que o processo de contratação teria de ser o mais transparente possível, e que deveria ter critérios objetivos de seleção de fornecedores de energia emergencial. O processo prático e objetivo implementado pelo Comitê evitou Que diferentes órgãos do Governo agissem de forma descentralizada, contratando energia da iniciativa privada e buscando soluçōes pontuais para o déftcit.

No processo de contratação de energia emergencial era fundamental o estabelecimento de um processo competitivo que resultasse no menor custo de energia para os consumidores, ou, eventualmente, para a União.

Qualquer que fosse o montante ou o mecanismo de contratação de energia nova, haveria uma interdependência entre as ações para o aumento da oferta em curto prazo e a sinalização emitida para os investidores de médio e longo prazo. O desafio do Comitê era o de adotar medidas que não enviassem os sinais errados ao mercado e que não prejudicassem o modelo do setor, afastando os investimentos privados de longo prazo, seja pela percepção do aumento excessivo de oferta, seja pela percepção de retorno ao modelo estatal. A alternativa implementada pelo Comitê de Contratação de Produtores Independentes de Energia, permitiu Que o montante de energia no sistema fosse suprido integralmente pela iniciativa privada, evitando novos investimentos estatais que, além. de onerar as empresas estatais, enfraqueceria a característica de participação e composição privada do modelo setor elétrico brasileiro.

Com essa finalidade foi criado um grupo técnico para verificar todos pontos supramencionados. Inicialmente, o Grupo de Execução fez um levantamento do potencial do mercando mundial para o atendimento das necessidades emergenciais. Em seguida, o Grupo coordenou com a Agência Nacional de Energia Elétrica - ANEEL e o Operador Nacional do Sistema- ONS o estabelecimento de regulação específica para as usinas emergenciais bem como a flexibilização nas regras dos procedimentos de rede. 
O Grupo de Execução teve a função de implementar todas as decisões do Comitê, ao longo de todas as fases do processo, desde a seleção e contratação dos Produtores Independentes até a efetiva entradas em operação das usinas.

o Comitê de Curto Prazo conduziu um processo minucioso de análise das diversas alternativas, até a decisão pelo lançamento da chamada pública para contratação de Produtores Independentes de Energia.

Diante da urgência e do volume de energia a ser contratado, fazia-se necessário que a contratação de energia fosse centralizada em apenas uma entidade. Para efetivar tal contratação, era necessária a definição de um agente contratante estatal, responsável por assinar os contratos de compra de capacidade e/ou energia de Produtores Independentes.

Inicialmente, o Comitê analisou as eventuais empresas já existentes Que pudessem efetuar tal papel. O Comitê concluiu que não havia uma entidade existente que pudesse atingir os objetivos requeridos sem ao mesmo tempo prejudicar alguns critérios cruciais para o sucesso do programa.

Uma das grandes dificuldades de se atribuir a uma empresa existente a contratação de energia emergencial foi, por exemplo, a Questão dos custos da energia emergencial. De modo a minimizar esses custos para os consumidores, o Comitê adotou como diretriz que a atividade de contratação não deveria produzir Qual Quer lucro para o agente contratante. Da mesma forma, em existindo lucro, o Comitê ponderou que esse lucro deveria ser revertido aos consumidores. Diante dessa diretriz, ficou evidente que o veículo de contratação enfrentaria algumas limitações caso se tratasse de uma companhia pública de capital aberto. podendo seus acionistas minoritários virem a Questionar as atividades relacionadas à viabilização da energia emergencial.

Após diversas discussões, a GCE orientou o Comitê que trabalhasse na criação de uma entidade nova, independente. Algumas das vantagens, pelo Comitê e pela GCE, Quanto à criação de uma nova entidade nova foram:

- Transparência Quanto aos custos da oferta emergencial;

- Prazo de existência determinado (enfatizando o caráter provisório desse processo); e - Sinalização correta e consistente com o modelo do setor elétrico.

Para assegurar o caráter transitório e emergencial dessa iniciativa, o próprio estatuto da CBEE contém a sua data de liquidação: 30 de junho de 2006. Os contratos de energia durarão somente até 31 de dezembro de 2005 . Isto evita a incorporação do custo da aQuisição em definitivo, às tarifas públicas de energia elétrica.

A GCE estabeleceu que o ONS seria responsável pelo cálculo das metas de contratação, segundo premissas de segurança definidas pela própria CGE.

lá em sua reunião inicial, no dia 06 de julho de 2001 , o Comitê requisitou ao ONS um diagnóstico do déficit emergencial, Que deveria considerar as adições de oferta já previstas 
e programadas pelo Ministério de Minas e Energia e pela ANEEL, incluindo usinas hidroelétricas e termoelétricas, importações de energia e linhas de transmissão Que viabilizasse a transferência entre as regiões do país. Esta informação deveria ser alinhada com um cronograma realista de execução de obras em andamento (diversas usinas hidrelétricas e térmicas estão por seu inauguradas até 2006).

A CBEE, portanto, foi criada para o fim de promover a aQuisição, o arrendamento e alienação de bens e direitos, a celebração de contratos e a prática de atos destinados:

1 - Viabilização do aumento de capacidade de geração e de oferta de energia elétrica de Qualquer fonte em curto prazo; $\mathrm{e}$

II - a superação da crise de energía elétrica e ao reequilibrio de oferta e demanda de energia elétrica.

Com o objetivo de proporcionar uma reserva de capacidade, a CBEE realizou contratos de reserva de geração para garantir oferta de energia elétrica em situações emergenciais (vide relação das contratações realizadas - anexo ()). Com a implementação do programa, foram estabelecidas as metas para que, mesmo se registradas as piores afluências hidrológicas do histórico para os próximos anos, a oferta de energia seja suficiente para atender a pelo menos $95 \%$ de todo o consumo. A contratação da energia emergencial protege e protegerá a população contra os efeitos catastróficos da eventual falta de chuvas nos reservatórios do sistema interligado. Daí serem chamados os encargos emergenciais popularmente de "seguro apagão".

A Medida Provisória n. ${ }^{\circ} 14$, de 21 de dezembro de 2001 , posteriormente convertida na Lei n. ${ }^{\circ} 10.438 / 02$, dispondo sobre a expansão de oferta de energia emergencial, estabeleceu a criação de "adicional tarilário espećfico", a cargo dos consumidores atendidos pelo Sistema Elétrico Nacional Interligado, para custeio das despesas relativas à aQuisição de energia elétrica e à contratação de capacidade de geraçâo ou potência, nos seguintes termos:

Art. Io Os custos, inclusive de natureza operacional, tributária e administrativa, relativos à aquisição de energia elétrica e à contratação de capacidade de geração ou potência pela Comercializadora Brasileira de Energia Emergencial - CBEE serão rateados entre todas as classes de consumidores finais atendidas pelo Sistema Elétrico Nacional Interligado, proporcionalmente ao consumo individual verificado, mediante adicional tarifário específico, segundo regulamentação a ser estabelecida pela Agência Nacional de Energia Elétrica - ANEEL.

$1^{\circ} \mathrm{O}$ rateio dos custos relativos à contratação de capacidade de geração ou potência $(\mathrm{kw})$ referidas no caput não se aplica ao consumidor integrante da Subclasse residencial Baixa Renda, assim considerado aquele que, atendido por circuito monofásico, tenha consumo inferior a $80 \mathrm{kWH} / \mathrm{mês}$ ou culo consumo situe-se entre 80 e $220 \mathrm{kWh} / \mathrm{mês}$, neste caso desde que observe o máximo regional compreendido na faixa e não seja excluído da subclasse por outros critérios de enquadramento a serem definidos pela Aneel. 
A Resolução n. ${ }^{\circ} 71$, de 07-02-2002 e a Resolução no 249, de 06-05-2002, foram editadas para regulamentar o previsto na norma legal acima, restando instituídos os seguintes encargos tarifários: a) "encargo de capacidade emergencial - ECE" - para rateio dos custos, inclusive de natureza operacional, tributária e administrativa, incorridos pela CBEE na contratação de capacidade de geração ou potência (arts. $\left(1^{\circ}\right.$ e $\left.2^{\circ}\right)$; b) "encargo de aquisição de energia elétrica emergencial - EAEE" - para rateio dos custos, inclusive de natureza operacional, tributária e administrativa, incorridos pela CBEE na aquisição de energia elétrica contratada (arts). ( $3^{\circ}$ e $4^{\circ}$ ); e, c) "encargo de energia livre adquirida no MAE" - para rateio da parcela prevista no art. $2^{\circ}$ da MP n. ${ }^{\circ}$ 4/0I, de despesa com a compra de energia elétrica no âmbito do MAE realizadas pelas distribuidoras e decorrentes da redução da geração de energia elétrica nas usinas participantes do Mecanismo de Realocação de Energia - MRE, denominada de energia livre (arts. $7^{\circ}$ e $8^{\circ}$ ).

Este último encargo tem por destinatários apenas os usuários do serviço de distribuiçâo de energia elétrica das regiōes sudeste, Centro-Oeste, Norte e Nordeste, conforme art. $4^{\circ}$ da Lel $n^{\circ} 10.438 / 02$. A controvérsia limita-se aos dois primeiros, já que o último, Encargo de Energia Live Adeuirida no MAE, representa restabelecimento do equilibrio econômico dos contratos de prestação de serviços de energia, não havendo discussão sobre a sua natureza jurídica.

Para minimizar custos, distinguiu-se a contratação de capacidade de geração (isto é, de disponibilidade) da aquisição de energia (isto é, da compra de energia efetivamente produzida). Assim, o contratado recebe um valor fixo pela disponibilidade (capacidade de potência -as usinas estão prontas para operar, coma devida manutenção e fiscalizaçâo da CBEE) e somente será remunerado pela energia se efetivamente vier a produzilla. Se se considerar que o custo mais relevante da energia de fonte termelétrica reside exatamente no preço do combustível na escala necessária, parece evidente a economicidade de uma tal contratação. A contratação de térmicas a óleo decorre exatamente da segurança na obtenção desse combustivel na escala necessária, pois o risco que se pretendia afastar reside exatamente na incerteza do suprimento do "combustivel" (água) das fontes hidrelétricas. 


\subsection{CONCEITOS JURÍDICOS IMPORTANTES NA DEFINIÇÃO DOS ENCARGOS TARIFÁRIOS}

Os normativos infralegais classificam os encargos de capacidade emergencial como um adicional tarifário, entendimento firmado por Sacha Calmon Navarro Coelho e Misabel Abreu Machado Derzi ${ }^{12}$. Contudo, levando-se em conta a regra do artigo $4^{\circ}$, I, do Código Tributário Nacional, o nome do instituto jurídico recebe não é o suficiente para demonstrar a sua estrutura. Neste Contexto, há Quem entenda que os adicionais tarifários năo se eneuadram em nenhuma das categorias de tributo veiculadas pela Constituição Federal de 1988, mas Que teriam natureza tributária ${ }^{13}$. Outros, como Lírio Pimenta ${ }^{14}$ e Neison Monteiro Neto ${ }^{15}$, entendem que seria uma contribuição de intervenção no domínio econômico. Um Quarto viés ${ }^{16}$ entende que seria uma espécie anômala de empréstimo compulsório. Na jurisprudência também não é differente, existindo os mais variados eneuadramentos, inclusive como imposto inominado e contribuição social geral ${ }^{17}$, mas está sendo sedimentado o entendimento de que o aludido encargo de capacidade emergencial tem natureza tarifária, como teremos oportunidade de demonstrar ${ }^{18}$.

Verifica-se, assim, Que essa Questão tem se prestado a diversos enfoques, gerando controvérsia na comunidade jurídica.

Para compreensão da natureza jurídica dos encargos emergenciais faz-se necessário trazer à consideração alguns conceitos envolvendo a definição de tributo e de tarifa, Que, necessariamente, deverão ser cotejados conjuntamente com a realidade do Setor Elétrico Brasileiro, objeto de capítulo anterior.

12 COELHO. Sacha Calmon Navarro; DERZ], Misabel Machado. Da constitucionalidade dos Encargos Emergenciais, institúlos pela Lei $N^{\circ} 10.438 / 02$. Parecer exarado em 20 de novembro de 2002, atendendo a Consulta da Associação Brasileira dos Produtores de Energia Emergencial- ABPEE.

${ }^{13}$ BIM, Eduardo Fortunato. Inconstitucionalidade dos encargos energéticos: seguro apagão. Revista Dialética de Direito Tributário, São Pauto, n. 82, p. 16-23, jul. 2002.

14 PIMENTA, P.R.L. Perfil constitucional das contribuiçōes de intervenção no domínio econômico. In: GRECO, M. A. (Coord.). Contribuições de intervençăo no donínio econômico e figuras afins. São Paulo: Dialética, 2001, p.155-184.

15 MONTEIRO NETO, N. Sobre o adicional tarifário em relaçăo aos serviços públicos de energia elétrica. Revista Dialética de Direito Tributário, São Paulo, n. 84, p. 94-100, set. 2002.

16 TAVARES, A. M. A falsa tipologia de adicional tarifário do "seguro-apagão" c as reflexas injurìicidades de sua cobrança. Revista Dialética de Direito Tributário, São Paulo, n. 87, p. 7-13, dez. 2002.

17 Posiçăo sustentada pelo Desembargador Federal Dirceu de Almeida Soares, no julgamento do incidente de argüição de inconstitucionalidade suscitada na apelação em Mandado de Segurança nº 2002.72.05.0028033/SC, na Corle Especial do TRF da 4a Região.

18 O Superior Tribunal de Justiça, através do voto do Ministro losé Delgado, no julgamento do recurso especial $n^{\circ} 692-550$, em 16 de dezembro de 2004, afirmou que "o referido encargo tem natureza de preço público", acompanhado pelos demais componentes da $1^{a}$ Turna. 
O conceito legal de tributo-estampado no artigo $3^{\circ}$ do Código Tributário Nacional"é toda a prestação pecuniária compulsória, em moeda ou cujo nela se possa exprimir, Que não constitua sanção de ato ilícito, instituída em lei e cobrada mediante atividade administrativa plenamente vinculada."

Extrai-se, assim, do conceito Que a prestação tributária é obrigatória. Não existe voluntariedade no pagamento do tributo, Que tem origem em expressa determinação legál, por imposiçâo do Estado; ao contrário do preço público, Que exige obrigaçôes contratuais e vontade daquele que assume a obrigação. Por isso é chamado de tributo sem causa, sem contra-prestação direta de Quem a pagou. Serve ao custeio geral das despesas do Estado. Por tal razão, o professor Geraldo Ataliba" ${ }^{19}$ classifica os tributos em vinculados (taxa e contribuição de melhoria) e não vinculados (impostos). No presente caso, nos interessa destacar a diferença entre tributo e preço público.

Aliomar Baleeiro ${ }^{20}$, explicando a distinção entre taxa e preços públicos, enfatiza a falta de compulsoriedade em relação aos serviços públicos remunerados por tarifas:

Mas a construção doutrinária penetrou na jurisprudência do Supremo Tribunal Federal, Que há vários anos distingue entre uns e outros, deixando claro Qúe só as taxas são tributos, como tais revestidos de compulsoriedade, ao passo Que os preços apresentam caráter contratual, voluntário, porque, em geral, remuneram a venda de coisas do patrimônio público ( terrenos, água, livro's, jornais oficiais, sementes, reprodutores, etc.) ou renda deles provenientes ( aluguéis, foros, laudêmios, serviços telefônicos, telegráficos, energia elétrica, etc).

A respeito da matéria, é esclarecedor o ensinamento do Juiz. Federal Leandro Paulsen ${ }^{21}$ :

Preço Público x Taxa. Deve-se ter bem presente a diferença entre taxa.e preço público. Aquela é tributo, sendo cobrada compulsoriamente por força de prestação de serviço público de utilização compulsória ou do Qual, de QualQuer maneira, o indivíduo não possa abrir mão. O preço público, por sua vez, não é tributo, constituindo, sim, receita originária decorrente da contraprestação por um bem, utilidade ou serviço numa relação de cunho negocial em Que está presente a voluntariedade (não há obrigatoriedade de consumo). A obrigação de prestar, pois, em se tratando de taxa, decore direta e exclusivamente da lei, enquanto, em se tratando de preço público, decorre

12 ATALIBA, Geraldo. Apontamentos de ciência das finanças do direito financeiro e tributário. Sấo Paulo: Revista dos Tribunais, 1969, p. 195

20 BALEEIRO, Aliomar. Limitą̧óes constilucionais ao poder de tributar. 7 ed. Rio de laneiro: Forense, 1988 , p.62.

2i PAULSEN, Leandro. Direito tributário: Constituição e Código Tributário à luz da doutrina e da jurisprudência. 7. ed. Porto Alegre: Livraria do Advogado, 2000, p. 39. 
da vontade do contratante. Por ter suporte no poder de tributar, submetendo os contribuintes de forma cogente; a exigência de taxas está sujeita às limitações constitucionais ao poder de tributar (art. $150 \mathrm{da}$ CF: legalidade, isonomia, irretroatividade, anterioridade, vedação de confisco). A fixação do preço público, de outro lado, independe de lei; não sendo tributo, não está sujeito as limitações do poder de tributar."

O preço público possui característica que o faz distinto de taxa, sendo elucidativo trazer as considerações de Carlos Valder do Nascimento ${ }^{22}$, Que destaca os seguintes traços Que o distingue das espécies tributárias:

a) é uma prestação contratual pecuniária, decorrente da aquisição de um bem, Que é alienado por uma entidade pública ou entidade privada, agindo por delegação, autorizaçăo, concessão ou permissão. Contratual aí se acha em sentido amplo, porque toda vez que o consumidor adquire um bem pelo Qual deve arcar com o pagamento de um preço ou tarifa estará realizando um vínculo contratual, ainda Que não o seja por escrito e ainda Que adira ao Que foi fixado pelo prestador da atividade de venda. É pecuniária a prestação, porque aferida em termos monetários;

b) é prestação facultativa, em decorrência mesmo da contratualidade. A facultatividade está no fato de Que o usuário ou adouirente do bem só pagará preço, se, efetivamente, Quiser firmar o contrato. É facultativo para o usuário adQuirir ou não o bem. Não haverá lei, impondo obrigação desse tipo, porém, mera manifestação de vontade;

c) exigibilidade do pagamento do preço pelo ente estatal ou por empresa privada, na condição de concessionária ou permissionária de serviço público (há Quem entenda Que ente estatal não pode cobrar preço público; apenas, entes privados autorizados pelo poder público, na manutenção de seu jus imperi);

d) remuneração de aQuisição de bem ou de serviço. O preço público é utilizado para pagamento de serviço ou aQuisição de bem, seja este produto de caráter industrial ou comercial, pouco importa. A contraprestação é marca indelével do preço público.

Assim, enquanto as taxas remuneram serviços públicos compulsórios, as tarifas remuneram serviços públicos de fruição voluntária, conforme se infere da Súmula 545 do Supremo Tribunal Federal: "Preços Públicos e taxas não se confundem, poreue estas diferentemente daqueles, são compulsórias e têm sua cobrança condicionada a prévia autorização, em relação à lèi Que as instituiu."

Iz NASCIMENTO, Carlos Valder do. Comentário ao CTN. Rio de Janeiro: Forense, 1994, p. 144-145. 
Destarte, para a caracterização da tarifa, em suma, é necessária a presença de dois requisitos: a) uma relação não compulsónia - ao beneficiário do serviço é facultada a utilização dos serviços disponibilizados. No caso da energia elétrica, nada impede a utilização de geradores próprios, sendo, portanto, contratual a relação com as concessionárias; b) um preço como contraprestação: o preço público é a remuneração pela utilização do ser viço ou aQuisição do bem pelo interessado.

O Supremo Tribunal Federal reconhece duas características da tarifa: destinar-se a concessionárias bem como à remuneração dos serviços prestados (aí incorporados todos os custos a eles eventualmente referidos, inclusive futuros). Nesse sentido, é expressiva a seguinte manifestação do ilustre Ministro Moreira Alves (em voto vencedor) no Recurso Extraordinário no $117.315-\mathrm{RS}$, in verbis:

E essa tarifa é o preço público Que corresponde à contraprestação remuneratória por parte do usuário de prestação, pela concessionária, desse serviço público facultativo, o Que implica dizer que é da essência dessa tarifa - como preço público que é - ter como destinatário o prestador do serviço. Que, com ela, não só tem a justa remuneração de seu capital, mas também dispóe de recursos para o melhoramento e a expansão de seus serviços, ben: como tem assegurado o equilíbrio econômico e financeiro do contrato.

Se é da essência da tarifa - como preço público Que é - ter como destinatário o prestador do serviço, Que dela se torna proprietário para os fins aos Quais ela visa por força do texto constitucional anteriormente referido e então vigente, Quer isso dizer que a sobretarifa, para ser um adicional da tarifa (e. portanto, também preço público), há de ter o mesmo destinatário - o prestador do serviço - - ainda Que tenha por fim reforçar apenas uma das parcelas (como é o caso da relativa ao melhoramento e à expansão do serviço) Que se levam em conta na fixação de seu valor. ${ }^{23}$

Não se pode deixar de mencionar, também, porque importante ao exame da controvérsia, o julgamento do RE no 209.365-3/SP, pela voz autorizada do Ministro Carlos Velloso, onde é feita a distinção entre serviços públicos essenciais e não essenciais, aplicandose aos primeiros a cobrança de taxas e aos últimos, porque delegáveis, de tarifas. O voto do Ministro Velloso reproduzia então orientação esposada no RE no $218.06 \mathrm{l} / \mathrm{SP}$ (D) de 08.09 .2000 , p. 00022). Afirmou-se, após se asseverar que a noção de serviços essenciais é de certo modo relativa, porque varia de Estado para Estado e de época. ${ }^{24}$

${ }^{23}$ RTI $132 / 888$.

${ }^{24}$ En conformidade com a lição de lèze citada RE no $89.876 /$ RI, Rel. Min. Moreira Alves, RTI no 98/238 e com texto resumido e adaptado da palestra do mesmo e eminente Ministro Moreira Alves publicado no Caderno de Pesquisas Tributárias, Săo Paulo, v. II co-edição Ed. Resenha Tributária e Centro de Estudos). 
A sua vez, a jurisprudência maciça do Superior Tribunal de lustiça, ao enfrentar Questôes relativas à majoração de tarifas de energia elétrica, tem sempre partido do pressuposto de Que efetivamente esta é a natureza jurídica da exação en comento: Resp.s 404.I 30/RS, 232.275/SP, 388.50I/RS, 303.215/MG e 194.476/DF (entendendo, nesse último julgado, Que exatamente por não possuir natureza tributária, a repetição de valores recohihidos a título de tarifa de energia elétrica se sujeita ao prazo prescricional de vinte anos), entre outros tantos julgados.

As empresas concessionárias de serviço público, como as distribuidoras de energia elétrica, são remuneradas através de tarifas ou preços públicos, conforme prevê o art. 175 da Constituição da República. Neste contexto, foi o próprio Constituinte quen estabeleceu regime de exceção às limitações constitucionais ao poder de tributar, exigindo apenas lei que defina a política tarifária e a obrigação de manter serviço adequado. E estes requisitos constitucionais foram observados, levando-se em conta Que a política tarifária emergencial foi estabelecida em lei exatamente com o objetivo de garantir o atendimento da demanda. Neste particular, cabe trazer à colação as observações do Professor Leandro Paulsen ${ }^{25}$ :

Serviços sob regine de concessão ou permissão. Regime de exceção. Art. 175 da CF. Licitação e lei de política tarifária. É importante ter em consideração Que a Constituiçăo, ao cuidar dos princípios gerais da atividade econônica, prevê a prestaçâo de serviço público por concessionárias ou permissionárias, estabelecendo regime específico para tal hipótese. $\mathrm{O}$ art. 175 da CF, de fato, parece estabelecer cláusula de exceção nestes casos, fazendo con que as salvaguardas do contribuinte (limitaçóes constitucionais ao poder de tributar) sejam substitú́das pela exigência de licitação ("sempre através de licitação") e pela política tarifária definida em lei ("A lei disporá sobre:... III- política tarifária;").

\section{PONTOS CONTROVERTIDOS NA DEFINIÇÃO DA NATUREZA JURÍDICA DOS ENCARGOS EMERGENCIAIS}

Feita esta rápida digressão a respeito dos conceitos, cabe enfrentar os pontos essenciais à definição da natureza jurídica dos encargos de capacidade emergencial, tais como compulsoriedade, contraprestação do serviço, destinação as concessionárias, eentres outros, Que são trazidos pelos operadores do direito na tentativa do seu enquadramento jurídico.

O Que se deve afirmar de pronto é que os recursos provenientes do adicional tarifário em nenhum momento serão destinados aos cofres públicos, mas apenas à contratação de

25 PAULSEN, Leandro. Direito Tributário: Constituição e Código Tributário à Luz da Doutrina e da lurisprudência. 7.ed.Porto Alegre: Livraria do Advogado,2005,p.39. 
capacidade de geração e potência das empresas que produzirão, eventualmente, a energia emergencial. Portanto, não constituem receita pública, já Que não são incorporados aos cofres da União ou de outra pessoa jurídica pública, o Que afasta a tentativa de enquadramento como imposto.

\subsection{Compulsoriedade do Serviço Prestado}

O primeiro ponto relevante que extraímos dos conceitos jurídicos trazidos, Que é um marco divisor na definição jurídica de Qualquer exação, diz respeito a compulsoriedade ou não do instituto objeto do presente trabalho de pesquisa. O argumento utilizado é de Que náo há como pagar o principal, ou seja, a tarifa de energia elétrica, sem pagar o encargo de capacidade emergencial, tendo em vista Que o não pagamento implicaria em suspensão do fornecimento de energia elétrica.

Cabe esclarecer Que a não compulsoriedade exigida pela tarifa refere-se ao serviço prestado ou posto à disposição e não à obrigação de contraprestação devida pelos consumidores do serviço já fruído (cf. Art. 79, I, alínea "b" do Código Tributário Nacional). Dai a importância de conhecermos como funciona o Sistema Elétrico Nacional Interligado para sabermos que a capacidade de potência e a energia emergencial são um componente do serviço prestado Que é remunerado pela tarifa, em face da situação emergencial existente no país. Os encargos foram criados para suportar os custos elevados da alternativa a escassez de água, no caso as usinas termoelétricas, movidas a óleo diesel. Houve necessidade de substituir rapidamente a capacidade de potência existente (baseado em água-hidrelétricas) por tecnologia existente no mercado (óleo diesel-termoelétricas), a fim de recompor esta capacidade por determinado tempo, garantindo o funcionamento do sistema.

Os serviços de geração, transporte e distribuição de energia elétrica não são compulsórios em razão de Que ninguém é obrigado a sequer consumir energia elétrica, ainda mais do Sistema Elétrico Interligado Nacional.

Ainda Que se Questionasse esta assertiva Quanto à existência ou não de obrigatoriedade de consumir energia elétrica em razão de sua essencialidade nos tempos atuais, no mínimo pode-se afirmar com segurança Que ninguém é obrigado a consumir energia proveniente do Sistema Elétrico Nacional Interligado. Sob este prisma é esclarecedor a lição do Professor Hugo de Brito Machado ${ }^{26}$ :

A título de exemplo, imaginemos a necessidade que se tem de energia elétrica. Se o ordenamento jurídico nos permite atender essa necessidade com a instalação de um grupo gerador em nossa residência, ou estabelecimento industrial, ou comercial, então a remuneração que o Estado nos cobra pelo fornecimento de energia é um preço público, pois não somos

\footnotetext{
26. MACHADO, Hugo de Brito. Curso de direito tributário. 1 l.ed. Sáo Paulo: Malheiros, 1996, p.330.
} 
juridicamente obrigados a utilizar o serviço para a satisfação da nossa necessidade. Embora seja mais conveniente a utilização do serviço público, do ponto de vista econômico, ou por outra razão Qualquer, do ponto de vista rigorosamente jurídico nada nos impede de, por outro meio, atender a necessidade de energia elétrica. A remuneração Que pagamos pelos serviços de fornecimento de energia elétrica, portanto, não é compulsória. Por outro lado, se há norma jurídica proibindo a instalação de grupo gerador, ou unidade de captação de energia solar, em residências, ou estabelecimentos comerciais ou industriais, de sorte que o atendimento da necessidade de energia elétrica, por Qualquer meio que não seja o serviço público, torna-se impossivel sem violação dão ordem jurídica, tem-se Que a utilização do serviço, e por isso mesmo o pagamento da remuneração correspondente, é compulsória. Neste caso, essa remuneração corresponde e à taxa.

Sobre a não compulsoriedade, ou de sua utilizaç̧ão, as leis ${ }^{27}$ são claras no sentido de permitir a produção independente de energia elétrica, podendo o usuário de desvincular do sistema, gerando e explorando a energia por meios próprios, situaçăo Que restou reforçada pela Lei $n^{\circ} 10.848$, de 15 de março de 2004 , Que trata da nova modelagem do Setor Elétrico Brasileiro, como tivemos oportunidade de demonstrar em capítulo antecedente.

Neste tópico, referente à não obrigatoriedade do consumo de energia elétrica do Sistema Interligado, são convincentes as lições do Ministro Moreira Alves ${ }^{28}$ :

"O problema, sim, é o de sabermos se o indivíduo, diante do serviço público prestado pelo Estado, tem, pelo menos, o direito de usar dele, sem sofrer punição por isso. Assim, por exemplo, o serviço de eletricidade é prestado pelo Estado ou por concessionário dele, mas não é compulsório, porQue se alguém Quiser não usar dele (preferir usar de fogão a carvão ou a gás engarrafado, e iluminar-se com vela ou lampião) não esta obrigado a valer-se desse serviço e, portanto, não está obrigado a pagar por ele. O mesmo sucede com a passagem de ônibus, que só é devida se o indivíduo se utiliza do veículo, sem estar obrigado a essa utilização, porque poderá ir ao seu destino a pé, de bicicleta, de táxi, de carro próprio, ou até mesmo não ir."

\footnotetext{
${ }^{27}$ A Constitujção Federal, no parágrafo $4^{\circ}$ do artigo 175, dispōe: "Não dependerá de autorização ou concessão o aproveitamento do potencial de energia renovável de capacidade reduzida." A Leĭ no 9074 , de 07 de jüho de 1995, no seu artigo $8^{\circ} \mathrm{diz:}$ "o aproveitamento de potenciais hidráulicos, iguais ou inferiores a $5.000 \mathrm{KW}$ e a implantaçăo de usinas termelétricas de potência igual ou inferior a $5000 \mathrm{kw}$, estăo dispensadas de concessão, permissão, ou autorização, devendo apenas ser comunicados ao poder concedente."

${ }^{28}$ BRASIL. Superior Tribunal de fustiça. RE 89.876. 4. Jul. 1980.
} 
Nesta linha, são elucidativas as Questóes apontadas pelo Desembargador Federal Antônio Albino Ramos de Oliveira ${ }^{29}$, segundo o Qual os requisitos para Que hạja cobrança de preço público, seja pelo concessionário/permissionário, sej̧a pelo Estado, é a prestação de serviços e sua utilização não coativa pelo usuário. Não há QualQuer dúvida de Que a tarifa de energia elétrica constitui um preço público, não tendo natureza tributária. Quanto à àquela "sobretarifa", instituída pela MP I 4/0I , parece evidente Que ela corresponde a uma prestação de serviços ao consumidor, remunerando expressamente, a energia emergencial contratada ou fornecida ao consumidor por intermédio da $\mathrm{CBBE}$. O uso dessa energia năo se tornou compulsório só pelo fato de ser emergencial: a compulsoriedade Que há em seu uso é só econômica, não jurídica, exatamente como ocorre com a energia fornecida em períodos de normalidade.

Reforçando esse entendimento são pertinentes as razóes trazidas pela Desembargadora Federal Maria Lúcia Leiria ${ }^{30}$ :

Desta forma, aqui não se trata de imposto, taxa ou sequer SIDE, porque a finalidade dos encargos está atrelada à prestação do serviço de energia elétrica, serviço este Que será ou nẫo utilizado pelo consumidor. Esta não obrigatoriedade de utilização da energia Que é gerada, mantida e distribuída nos termos do artigo 175 da Constituição Federal, faz com Que, aqui, não revista dos elementos configuradores de tributo onde há a compulsoriedade da cobrança e da utililzação, no caso, dos serviços públicos essenciais.

Os adicionais tarifários são destinados ao custeio do serviço e, portanto, caracterizamse como tarifas. Esta afirmação decorre do fato de Que não se pode desconsiderar a existência de uma cadeia formada pela geração, transmissão e distribuição de energia elétrica, todas as etapas remuneradas pela tarifa cobrada dos usuários finais, em Que pese o pagamento seja efetuada apenas na ponta a empresa Que comercializa, Que não é a Que gera a energia muitas vezes, como referida no capítulo que trata do Sistema Elétrico Brasileiro.

A definição fornecida pela Agência Nacional de Energia Elétrica é esclarecedora:

A tarifa de energia elétrica aplicada aos consumidores finais regulados representa a síntese de todos os custos incorridos ao longo da cadeia produtiva da indústria de energia elétrica: geração, transmissão, distribuição e comercialização. O seu valor dever ser suficiente para preservar o princípio da modacidade tributária e assegurar a saúde econômica e financeira das concessionárias, para Que possam obter recursos suficientes para cobrir seus custos de operação e manutenção, bem como remunerar de forma justa o

₹. TRIBUNAL REGIONAL FEDERAL 4ª Região. Mandado de Segurança $\pi^{\circ}$ 2002.72.05.002241-9/SC. D/U 2 JUก. 2004.

30 TRIBUNAL REGIONAL FEDERAL 4a Região. Agravo de Instrumento $n^{\circ}$ 2003.04.01.038403-1/RS, D/U 19 nov. 2003. 
capital prudentemente investido com vista a manter a continuidade do serviço prestado com a Qualidade desejada.

Portanto, Qualquer aumento ou diminuição de custos em Qualquer fase da cadeia energética é atinente ao serviço público como um todo e Que deve ser remunerado pelos usuários do próprio serviço público (isso não impediria, caso fosse a opção da política governamental, Que tal despesa adicional e emergencial fosse suportado pelos recursos advindos da tributação geral).

\subsection{Contraprestação do Serviço de Energia Elétrica}

Outra Questão importante para desvendarmos a estrutura jurídica dos adicionais tarifários está ligada à contraprestação do serviço. Ai novamente faz-se nécessário conhecer como funciona o Sistema Elétrico Interligado Nacional. O consumo de energia, como é cediço, não é uniforme durante todos os meses do ano, o Que não desobriga a geradora de manter-se em funcionamento nos meses de menor consumo. Há os momentos de pico e a própria perspectiva de crescimento do país, devendo o Sistema responder, sob pena de entrar em colapso. De outra parte, não há como se armazenar energia. Com a estiagem ocorrida em 2001, o Sistema existente no país, baseado em Hidroelétricas, não tinha como responder a totalidade da demanda, chegando a haver apagóes em algumas cidades. Para garantir o funcionamento total do sistema por um determinado tempo, mesmo em situaçôes hidrológicas desfavoráveis, até Que ficassem prontas novas usinas em implantação no país, é Que motivou à busca da energia alternativa a água. Daí a contratação de usinas térmelétricas Que estão a disposição do sistema interligado nacional, custeadas pelo "Encargo de Capacidade Emergencial-ECE". É a chamada disponibilização da potência, importante para o efetivo funcionamento do sistema, garantindo Que não haverá falta do produto energia elétrica Quando o consumidor precisar. É como se fosse o reserva no time de futebol. Na falta do titular, ingressa para garantir o conjunto, mas nem por isso deixa de ser remunerado. No caso de falta de energia para o suprimento do país as usinas emergenciais são ligadas ao Sistema Interligado Nacional, ocasionando outro Encargo, o " Encargo de Aquisição de Energia Elétrica Emergencial - EAEI". Razão pela Qual não calham os argumentos de Que os adicionais não têm QualQuer relação com a efetiva prestação do serviço. Ao contrário, são essenciais para garantir a continuidade do serviço, em face de fatores climáticos, não pondo a risco de colapso do sistema interligado nacional, cujas conseQüências seriam danosas para os usuários e para o país. E as Usinas estão à disposição do sistema, exigindo manutenção periódica. E efetivamente foram acionadas em diversas oportunidades. 
Nesse ponto, vale citar trecho do acórdão proferido pela Corte Especial do Tribunal Regional Federal da $4^{a}$ Região ${ }^{31}$, in verbis.

Sendo a capacidade de geração um componente do Sistema, de responsabilidade dos agentes respectivos e a ser remunerado por tarifa, não haveria como concluir, sob o argumento da inexistência de prestação de serviço público, Que um adicional a esse serviço, como o encargo de capacidade emergencial, não deva ser remunerado por sobre tarifa ou adicional.

A receita do adicional tarifário específico, portanto, destina-se a custear os serviços de aQuisição e distribuição de energia elétrica emergencial, valor que integra o custo final do serviço. Presente, portanto, o caráter de contraprestação, vez Que a remuneração pelo serviço engloba necessariamente o rateio proporcional entre os consumidores do custo total do serviço.

\subsection{Destinação dos Encargos a CBEE}

Não se pode deixar de considerar, também, Que a criação de um agente comercializador sem resultados financeiros Que repassa os custos de contratação dos agentes de geração termelétrica decorre exatamente da circunstância de Que o despacho da energia é centralizado junto ao ONS e as exposiçôes financeiras são liquidadas em um mercado atacadista, o Que transcende contratos bilaterais, define a reserva de geração como um serviço prestado a todo os consumidores do sistema interligado e exige o rateio integral dos custos entre todos esses consumidores.

A destinação dos adicionais tarifários a CBEE, Que efetua a contratação das usinas emergenciais, e não diretamente as empresas concessionárias/permissionárias, outro argumento utilizado, não desvirtuam sua natureza tarifária. Em primeiro lugar, porque a CBEE, conQuanto receba os adicionais, não os incorpora ao seu patrimônio. Tanto Que o $3^{\circ}$ do art. $1^{\circ}$ da Lei $n^{\circ} 10.438 / 02$, fixa Que os resultados financeiros obtidos pela CBEE serão destinados a redução dos custos e serem rateados entre os consumidores. lá ocorreram três reduçōes do valor dos encargos. A última, no mês de julho/2005, representa decréscimo de $41,67 \%$ do valor do encargo de capacidade emergencial ${ }^{32}$.

A CBEE insere-se na cadeia de prestadores de serviços do sistema interligado. A interposição da CBEE nessa cadeia apenas se destinou a centralizar as operações de compra, equalizando preços e organizando o mercado, o Que não seria possível se cada uma das fornecedoras fossem buscar individualmente no mercado suas necessidades extraordinárias de energia.

3) TRIBUNAL REGIONAL FEDERAL 4a Região. Apelação em Mandado de Segurança no 2002.72.05.002803-3/SC. Relator para acórdão: Des. Luis Fernando Penteado. D/U 8 set. 2004.

32 AGÊNCIA NACIONAL DE ENERGIA ELÉTRICA. Resolução Homologatória no /54/2005. 
Esta impressão ficou bem delineada na manifestação do Desembargador Federal Vilson Darós, no julgamento do incidente de inconstitucionalidade pela Corte Especial do Tribunal Regional Federal da $4^{\text {a }}$ Região:

Para melhor entendimento, cumpre, aQui, uma breve digressão a respeito do Sistema Nacional Interligado. A energia elétrica, é um bem econômico negociável e não armazenável. Sua circulação dá-se pelo Sistema Nacional Interligado, Que é constituído por linhas de transmissão e distribuiçăo Que ligam as geradoras de energia elétrica aos consumidores de todo o país. A função da administração é coordenar essas operações de geração, transmissão e distribuiç̧ão de energia elétrica, sempre visando à continuidade o serviço.

Dentro desse contexto insere-se a CBEE, Que, ao contratar capacidade de geração, repassa valores dos encargos às empresas distribuidoras. Pode-se afirmar Que a Comercializadora Brasileira de Energia Elétrica não é o destinatário dos valores pagos,"

Cabe lembrar que a remuneração do Operador Nacional do Sistema (ONS), empresa responsável por gerir de forma unificada o Sistema Elétrico Nacional Interligado, integra o custo pago pelos usuários finais, conforme se pode extrair do disposto na Lei n ${ }^{\circ} 9.648 / 98$, regulamentado pelo Decreto $2.655 / 98$ e pelas Resoluções números 351/98 e 281/282 de 1999 da ANEEL. Em outras palavras, na tarifa, antes mesmo da instituição da sobretarifa cobrada a partir da MP 14/200 I, estava incluída parcela destinada ao Operador Nacional do Sistema, o que nunca foi objeto de Questionamento.

Resta claro, assim, Que a passagem dos recursos pela CBEE não tem o condão de interferír na definição da natureza jurídica da cobrança como tarifa, levando-se em conta Que se trata de empresa constituída com prazo determinado para sua extinção e com o propósito específico afeto diretamente ao serviço que é objeto da tarifa e de sobretarifa: o fornecimento de energia elétrica.

Tais características não se inserem no conceito de tributo previsto no art. $3^{\circ}$ do Código Tributário Nacional, especialmente por não ser obrigação pecuniária compulsória.

De fato, o adicional tarifário espeć́fico, como a própria denominação evidencia, não é tributo. Cuida-se tão-somente - tal como a tarifa ordinária - de contraprestação destinada a remunerar os serviços prestados pelas pessoas jurídicas privadas (concessionárias ou permissionárias) Que exploram os serviços de energia elétrica. Não se destinam, ademais, aos cofres públicos, característica elementar das imposições de caráter tributário.

Nesse contexto, não se pode atribuir aos "adicionais tarifários", previstos na Lei $n^{\circ}$ [0.438/02 e regulamentados pela Resolução n. ${ }^{\circ} 7$ I/02 da ANEEL, outro enquadramento conceitual senão o de "tarifa", uma vez Que preenchem as características supra-referidas. 


\subsection{Os encargos fazem parte da Política Tarifária Emergencial para custear o Sistema}

A criação de adicional tarifário específico para fazer frente a esses custos mostra-se conforme ao direito em vigor e à tradição do Setor.

Relativamente ao direito em vigor, reconheceu o Supremo Tribunal Federal, no julgamento da Açáo Declaratória de Constitucionalidade no 9-6/DF, Que tarifas públicas, por decorrência do inciso Ill do parágrafo único do art. 175, integram uma "política tarifária" e constituem, portanto, "preços políticos".

Nessa linha, a manifestação do Ministro do Supremo Tribunal Federal, Carlos Velloso, julgamento da supracitada ADC:

Essa tarifa especial, ademais, destina-se a remunerar custos ampliados das concessionárias e distribuidoras de energia elétrica, com a execução das resoluções da Câmara de Gestão da Crise de Energia Elétrica. Tem-se, com essa tarifa especial, redistribuição, de forma isonômica, de custos, sob condições de escassez: financiamento do bônus por exemplo, aos Que poupam mais, o Que foi ressaltado nos votos Que me precederam, especialmente no voto do Ministro Nelson Jobim. Parece-me precedente, de outro lado, o argumento no sentido de Que, num sistema de escassez do serviço, possa o legislador realizando política tarifária Que the incumbiu a Constituição, cobrar mais caro pelo serviço Que excede à cota destinada ao consumidor. Tudo isso comporta-se no conceito de política tarifária, tornando realidade no mundo das coisas.

Tal circunstância confere à lei a prerrogativa de disciplinar amplamente a forma de remuneração e distribuição de custos de determinada prestação de serviço público. Foi exatamente nesse contexto Que o STF declarou constitucional a cobrança de tarifa especial daqueles Que, durante o racionamento, extrapolassem a respectiva meta de consumo de energia elétrica.

Esta discussão nos leva a indagação, sempre trazida, sobre a possibilidade de haver preço público, fora da política tarifária. Pelo tudo Que foi depreendido não há como se deixar de considerar que a capacidade emergencial contratada pela CBEE, para garantir o fornecimento de energia elétrica, integra o custo do Sistema Interligado, e como tal deve ser custeado pelo preço da tarifa. Poderia até ser realizado pelas concessionárias, o Que certamente traria especulações na contratação de energia alternativa à água, e embutido no preço da tarifa mediante simples reajuste. Como alternativa foi emergencial e temporária a opção foi à criação dos adicionais. Faz parte, assim, da política tarifária emergencial e temporária, estabelecida em lei para fazer frente a necessidade do serviço energia elétrica, evitando a sua descontinuidade e o apagão. 
É de se destacar, também, Que estamos diante de um setor econômico cuj̣os preços são regulados pelo governo, logo, não decorrem livremente das partes, daí ser possível o aumento unilateral pela Agência Reguladora, observado os custos existentes logicamente. O fato de o adicional vir destacado na fatura não modifica sua natureza tarifária, apenas dá transparência aos valores pagos.

De resto, a sistemática introduzida reproduz aquela da denominada Conta de Compensação de Combustível $-\mathrm{CCC}$, por meio da Qual também o custo dos combustíveis termelétricos é repartido entre os consumidores (sistemática em vigor desde a edição do art. 13, III, da Lei no 5.899, de 05 de julho de 1973).

Patente está o que seja tarifa e o seu caráter de contraprestação pelos serviços (serviço público não essencial e delegável, ainda que o bem fornecido - energia elétrica seja considerado essencial), estando cristalina a conformação entre o Que é pago e o que é cobrado ao consumidor pelo serviço.

A fixação da contraprestação dos serviços públicos está sujeita ao atendimento do disposto na Lei no 8.631, de 04.03.1993, regulamentada pelo Decreto no 774, de 18.03. 1993, normas que tratam da fixação dos níveis de tarifa para o serviço público de energia elétrica, estando claro Que a fixação da tarifa difere substancialmente da fixação do Quantum debeaturnos tributos.

Dispõe o art. $2^{\circ}, \S 2^{\circ}$ da Lei no $8.631 / 93$ Que "Os níveis das tarifas a que se refere o 'caput' deste artigo corresponderão aos valores necessários para cobertura do custo do serviço de cada concessionário supridor, segundo suas características específicas, de modo a garantir a prestação dos serviços adeQuados."

As medidas legais que criaram os encargos não excluem a não-compulsoriedade das tarifas, apenas se reconhece que, em virtude da situação hidrológica crítica por Que passou o País e da necessidade de se manter o atendimento à demanda crescente por energia, trouxeram custos ao sistema.

Há que se considerar, também, para o fato de que o aumento das tarifas está sujeito à homologação, Que é um ato normativo e nem por isso faz de sua fixação um ato compulsório (art. $1^{\circ}, \S 1^{\circ}$. Lei $8.631 / 1993$ ).

Ademais, a instituição dos encargos não se deu por Resolução da ANEEL e sim pela MP 14 de 2 1.12.2001, posteriormente convertida na Lei n ${ }^{\circ} 10.438 / 02$, não se ferindo o princípio da legalidade. Tal lei autorizou a instituição dos encargos, cuja disciplina restou afeita ao poder regulamentar. Os atos administrativos relativos ao reąiuste tarifário seguiram aos ditames ínsitos no princípio da legalidade, Quais sejam a urgência e a relevância.

De outra parte, descabe argumentar que a base de cálculo ou alíquota não foram previstas por lei, mas por resolução da ANEEL, consabido que a base de cálculo é o custo da disponibilização, rateado na proporção da demanda de consumo médio de cada consumidor; a alíquota não deve vir fixada na lei, poreue se trata de rateio integral dos custos, na proporção do consumo anterior, demais de os tributos nem sempre suporem base de cálculo. 


\subsection{Comparaçáo com o Fundo Nacional de Telecomunicações e o Adicional de Tarifa Pontuária}

Outra Questão sempre trazida pelos operadores do direito é com relação à comparação feita ao Fundo Nacional de Telecomunicações (FNT) e o Adicional de Tarifa Portuária (ATP). no Que tange ao destinatário não ser a concessionária do serviço e por destinar os valores a um fundo de investimentos para novos usuários do setor.

O precedente do Fundo Nacional de Telecomunicações é invocado equivocadamente, pois se destinava a captar recursos dos usuários atuais dos ser viços de telecomunicações para expandir os serviços para novos usuários, en®uanto o valor arrecadado pela CBEE é pago e aproveitado pelos usuários atuais do Sistema Elétrico Nacional, não servindo para expandir ou captar novos usuários. No caso das telecomunicaçōes, ainda, a tarifa é paga diretamente ao concessionário por ele ser o único prestador do serviço, ao contrário do setor elétrico Que tem várias etapas, como a geração e distribuiçao de energia, @ue ora podem ser concessionários ou ora podem ser autorizados. De outra parte, a CBEE já presta seus serviços disponibilizando de imediato ao Sistema Interligado Nacional um aumento de capacidade de geração de aproximadamente $2.000 \mathrm{MW}$, por intermédio de 50 usinas contratadas e em operação, conforme demonstrado em capítulo anterior. Não procede também a informação de Que o adicional remunera a instalação das usinas, visto Que estas somente passaram a aferir receita após devidamente instaladas e testadas com despachos de geração de energia. A instalação ocorreu por conta e risco do empreendedor da Usina.

Corrobora este posicionamento, a manifestação da $1^{\circ}$ Turma do Tribunal Regional Federal da $4^{a}$ Região ${ }^{33}$, cujo trecho se transcreve:

[...] Entendo, porém, Que não há Qual@uer similaridade entre os dois casos. Ali se discutia uma sobretarifa Que não tinha QualQuer vinculação direta com a prestação dos serviços Que era objeto das tarifas telefônicas, sendo direcionada ao Fundo Nacional de Telecomunicaçōes (depois, a Embratel, à Telebrás, ao Fundo Nacional de Desenvolvimento). "Eram recursos destinados ao financiamento do Sistema de telecomunicações nacional, e não à prestação dos respectivos serviços."

AQui, pelo contrário, a sobretarifa cobrada diz respeito diretamente aos serviços Que dão origem à tarifa. $O$ fato de ser destinada à $\mathrm{CBEE}$, e não a distribuidora, não desvirtua sua natureza remuneratória [...]

33 TRIBUNAL REgIONAL FEDERAL 4a Regiăo. Apelação em Mandado de Segurança $\pi^{\circ}$ 2002.72.05.00224 1 -9/SC. Relator: Des. Antônio Albino Ramos de Oliveira. 
De outra parte, o adicional de tarifa portuária- ATP também não serve como paradigma aos encargos emergencias. Como referido, Qualquer usuário dispõe de vários meios para obtenção de energia elétrica. O Sistema Interligado Nacional, cuj̣a utilização dá ensejo à cobrança do encargo, é apenas um destes meios. Daí porque a afirmação de Que sua natureza é tarifária, ao contrário do ATP, cuja prestação é compulsória, não havendo meios alternativos portuários a obtenção dos serviços portuários.

\subsection{Observância do Princípio da Proporcionalidade}

Por fim, outro aspecto relevante para se aferir a instituição do encargo é o de verificar o respeito ao princípio da proporcionalidade, utilizando-se da forma preconizada pelo Ministro Gilmar Ferreira Mendes ${ }^{34}$, (l) da legitimidade dos meios utilizados e dos fins perseguidos pelo legislador; (II) da adequação desses meios para consecução dos objetivos pretendidos; e (III) da necessidade de sua utilização.

No que diz respeito ao primeiro dos pressupostos elencados, cumpre destacar Que, com a instituição do encargo, o fim perseguido é o custelo das atividades da CBEE com a contratação de energia emergencial, o Que visa beneficiar a sociedade e atender o princípio da continuidade dos serviços públicos de energia elétrica. De outra parte, o meio utilizado é o rateio entre os consumidores na proporção de seu consumo individuais, excluídos os considerados de "baixa renda" e outros menos favorecidos. Verifica-se, portanto, que os meios utilizados e os fins pretendidos com a instituiçāo dos encargos são legítimos.

Com relação à adequação da medida adotada para alcançar o fimm proposto também encontra legitimidade, na medida em que os recursos captados serão custeados os gastos da CBEE com serviços Que garantirâo a oferta de energia elétrica em situações emergenciais, oferecendo condiçôes para Que, mesmo se registradas as piores afluências hidrológicas dos históricos para os anos 2002/2005, a oferta de energia será suficiente para atender pelo menos $95 \%$ de todo o consumo.

A necessidade da medida também se afigura presente, pois a suspensão no fornecimento de energia do fornecimento de energia elétrica afeta o crescimento do país e o bem estar da população. O serviço prestado pelo CBEE, custeado pelos encargos, propiciará a compatibilidade da demanda e da oferta de energia elétrica, evitando, assim, um colapso do sistema, assim como o atendimento da continuidade dos serviços públicos.

Cabe observar, também, Que não houve Qualquer excesso na instituição dos encargos, não gerando QualQuer lucro à CBEE e, na hipótese de ocorrer, será revertido aos consumidores, como antes referido.

${ }^{34}$ MENDES, Gilmar Ferreira. Hermenêtitica constitucional e os direitos fundamentais. Brasilia: Jurídica, 2002. p. 250 . 


\section{CONCLUSÓES}

I-A crise energética foi uma realidade inconteste, o Que tem demandado ampla intervenção do Poder Executivo Federal no sentido de compatibilizar a demanda e a oferta de energia elétrica, bem assim de prevenir as chamados apagões;

II - A CBEE é empresa pública, com o fim de promover a aquisição, o arrendamento e a alienação de bens e direitos, a celebração de contratos e a prática de atos destinados à viabilização do aumento da capacidade de geração e da oferta de energia elétrica de QualQuer fonte em curto prazo, à superação da crise de energia elétrica e ao reecuilíbrio de oferta $\mathrm{e}$ demanda de energia elétrica;

III - A contratação de energia emergencial protege e protegerá a população contra os efeitos catastróficos da eventual falta de chuvas nos reservatórios do sistema interligado;

IV - O Encargo de Capacidade Emergencial não é tributo, já Que nem os recursos provenientes da recomposição tarifária extraordinária, nem do pagamento do adicional tarifário, em momento algum, serão destinados aos cofres públicos, mas ao custeio do serviço. Esta afirmação decorre de Que não se pode desconsiderar a existência de uma cadeia formada pela geração, transmissão e distribuição de energia elétrica, todas etapas remuneradas pela tarifa. E a capacidade de potência é um componente do Sistema Interligado, para garantir o seu funcionamento contínuo. Portanto, o produto da arrecadação não constitui receilta pública, os recursos não são incorporados aos cofres da União, mas servem ao custeio do serviço;

$\mathrm{V}$-É coerente a natureza jurídica do adicional tarifário específico como de tarifa, sobretudo Quando se considera a possibilidade de devolução ao consumidor, mediante diminuição da tarifa, dos resultados financeiros apurados pela CBEE em decorrência da comercialização de energia elétrica (art. $I^{\circ}, \S 3^{\circ}$, da Medida Provisória $n^{\circ}$ [4/2001). circunstância Que efetivamente vem ocorrendo;

V-A decisão do Supremo Tribunal Federal na $A D C n^{\circ} 9$ reviu sua jurisprudência firmada sob a Constituição anterior acerca dos, até então, estritos e constitucionais caracteres da tarifa e, sob o mote da política tarifária, deferiu amplo espaço de conformação das tarifas ao legislador;

VII - A criaçâo de um agente comercializador sem resultados financeiros Que repassa os custos de contratação dos agentes de geração termelétrica decorre exatamente da circunstância de que o despacho da energia é centralizado junto ao Operador Nacional do Sistema (ONS) e as exposições financeiras são liquidadas em um mercado atacadista, o que transcende contratos bilaterais, define a reserva de geração como um serviço prestado a todos os consumidores do sistema interligado e exige o rateio integral dos custos entre todos esses consumidores;

VII - É destituída de fundamento a afirmação de que os adicionais tarifários específicos seriam tributo, uma vez que a relação entre os consumidores e as distribuidoras é de consumo, ensejando, então, uma relação negocial, Que nada tem a ver com a relação tributária, configurando-se claramente uma relação de consumo; 
IX - Os encargos de capacidade emergencial (art. $1^{\circ}$ da Lei 10.438/02) e de aquisição de energía elétrica (art. $3^{\circ}$ ) não têm natureza tributária:

a) não são impostos, porque sua cobrança não se refere a uma situação do contribuinte alheia à atividade do Estado, exercida ainda que indiretamente por empresa pública, dele uma extensão;

b) não são taxas, porque, apesar de o fornecimento de energia elétrica ser um serviço público, é remunerado mediante tarifa (preço público); é uma atividade de natureza industrial e comercial situada no âmbito privado (ainda que regulada pelo Poder Público) $e$ não se reveste do caráter da compulsoriedade, pois ao cidadão resta a possibilidade de não ser usuário ou consumidor dos serviços de energia elétrica, podendo instalar um gerador, optar pela energia solar, eólica ou outras alternativas;

$X$ - Não sendo tributos, a esses adicionais não se aplicam os princípios constitucionais tributários, em especial os da legalidade e da anterioridade, nem a regra do art. $155, \S 3^{\circ}$, da Constituição da República;

XI - O artigo 175 da Constituição Federal estabelece cláusula de exceçâo as salvaguardas das limitações constitucionais ao poder de tributar, prevendo que os serviços prestados sob o regime de concessão ou permissão serão remunerados por tarifa, exigindo lei que defina política tarifária e obrigação de manter serviço adequado, requisitos observados pela política tarifária emergencial, constante da Medida Provisória ${ }^{\circ}$ [4, de 21 dezembro de 2001, convertida na Lei $n^{\circ} 10.438$, de 26 de abril de 2002;

XIII - Não há desrespeito ao princípio da proporcionalidade, havendo legitimidade dos meios utilizados e dos fins perseguidos pelo legislador; adequação desses meios aos objetivos pretendidos e necessidade de sua utilização.

\section{REFERÊNCIAS BIBLIOGRÁFICAS}

ATALIBA, Geraldo. Apontamentos de ciência das finanças do direito financeiro e tributário. São Paulo: Revista dos Tribunais, 1969.

BALEEIRO, Aliomar. Limita̧̧ôes constitucionais ao poder de tributar. 7 ed. Rio de laneiro: Forense, 1988.

BIM, Eduardo Fortunato. Inconstitucionalidade dos encargos enérgéticos: seguro apagão. Revista Dialética de Direito Tributário, São Paulo, n. 82, p. 16-23, jul. 2002.

CAMPOS, Clever M. Introdução ao direito de energia elétrica. São Paulo: Ícone, 2001.

COELHO, Sacha Calmon Navarro; DERZI, Misabel Machado. Da constitucionalidade dos Encargos Emergenciais, instituidos pela Lei No 10.438/02. Parecer exarado em 20 de novembro de 2002, atendendo a Consulta da Associaçáo Brasileira dos Produtores de Energia EmergencialABPEE. 
CONSULTORIA-GERAL DA UNIÃO. Coordenação-Geral de Grupos Especiais. Açôes envolvendo a MPIA.

MACHADO, Hugo de Brito. Curso de direito tributário. 1 l.ed. São Paulo: Malheiros. 1996.

MAXIMILIANO, Carlos. Hermenêutica e aplicação do direito. Rio de Janeiro: Forense. 1984.

MENDES, Gilmar Ferreira. Hermenêtutica constituciona/e os direitos fundamentais. Brasilia: Jurídica, 2002.

MONTEIRO NETO. N. Sobre o adicional tarifário em relação aos serviços públicos de energia elétrica. Revista Dialética de Direito Tributário, São Paulo, n. 84, p. 94-100, set. 2002.

NASCIMENTO, Carlos Valder do. Comentário ao CTN. Rio de Janeiro: Forense, 1994.

PAUSEN, Leandro. Direito tributário: Constituição e Código Tributário à luz da doutrina e da jurisprudência. 7. ed. Porto Alegre: Livraria do Advogado, 2005.

PIMENTA, PR.L. Perfil constitucional das contribuiçōes de intervenção no domínio econômico. In: GRECO, M. A. (Coord.). Contribuiçôes de intervenção no domínio econômico e figuras alins. São Paulo: Dialética, 200 I . p. I55-I 84.

SOUTO, Carlos Fernando E.; LOUREIRO, Gustavo Kaercher. O novo modelo do setor elétrico brasileiro e as Cooperativas de Eletrificaçäo Rural. Porto Alegre: Livraria do Advogado, 1999.

TAVARES, A. M. A falsa tipologia de adicional tarifário do "seguro-apagão" e as reflexas injuridicidades de sua cobrança. Revista Dialética de Direito Tributário, São Paulo, n. 87, p. 7-13, dez. 2002. 